
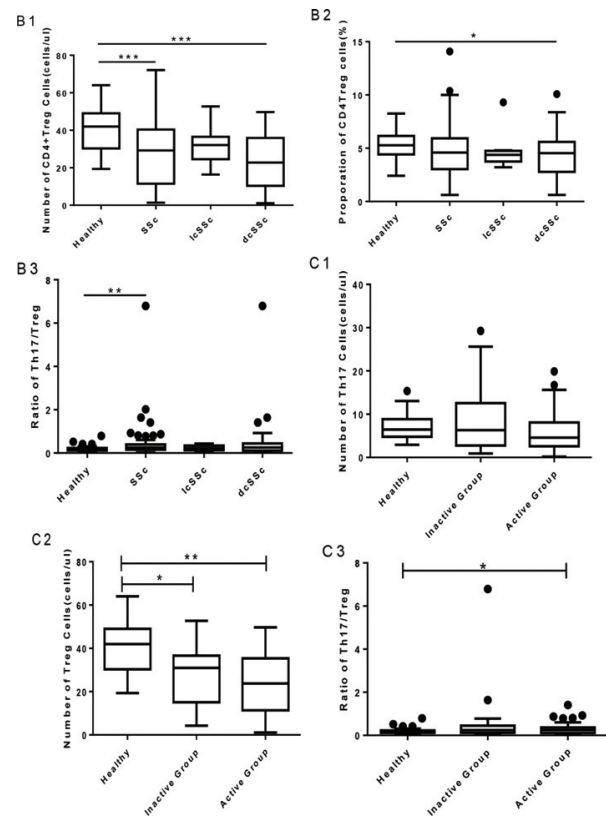

Figure 2. Absolute number of peripheral Th17 and Treg cells in SSc patients with different performance and disease activity. (B1 and B2) The absolute number of Treg cells was significantly reduced in patients with SSc, particularly more pronouncedly in patients with dcSSc. (B3) The ratio of Th17/Treg cell was increased in SSc patients. (C1) The absolute number of Th17 cells was not significantly changed but (C2 and C3) that of CD4Treg cells in active group with SSc decreased significantly, thus causing an increase in the ratio of Th17 and Treg cells. ${ }^{*} P<0.05 ;{ }^{* *} P<0.01 ;{ }^{* *} P<0.001$. IcSSc: localized sclerosis, dcSSc: diffuse sclerosis.

Disclosure of Interests: None declared DOI: 10.1136/annrheumdis-2019-eular.6137

\section{AB0687 EFFECTIVENESS OF SPECIALIZED AND INTENSIVE ADL TRAINING IN PATIENTS WITH IDIOPATHIC INFLAMMATORY MYOPATHIES - PRELIMINARY RESULTS OF A ONE-YEAR CONTROLLED STUDY}

${ }^{1}$ Maja Špiritović ${ }^{*}$, Sabina Oreska², Hana Štorkánová ${ }^{2}$, Barbora Heřmánková1, Petr Česák ${ }^{3}$, Adéla Rathouská ${ }^{4}$, Kateřina Kubinova² ${ }^{2}$ Martin Klein², Lucia Vernerová2 ${ }^{2}$, Olga Růžičková2 ${ }^{2}$, Heřman Mann ${ }^{2}$, Karel Pavelka², Ladislav Šenolt ${ }^{2}$, Jiři Vencovský2 ${ }^{2}$, Michal Tomčík ${ }^{2} .{ }^{1}$ Faculty of Physical Education and Sport, Charles University, Department of Physiotherapy, Prague, Czech Republic; ${ }^{2}$ Institute of Rheumatology, Department of Rheumatology, 1 st Faculty of Medicine, Charles University, Prague, Czech Republic; ${ }^{3}$ Faculty of Physical Education and Sports, Charles University, Human Movement Laboratory, Prague, Czech Republic; ${ }^{4}$ Institute of Rheumatology, Prague, Czech Republic

Background: Idiopathic inflammatory myopathy are characterized by muscle weakness, caused by inflammation and immune changes in the affected muscles, which lead to a limitation in the execution of day-today activities (ADL). The aim of our study was to investigate the impact of specialized and intensive ADL training on muscle strength and endurance, depression and QoL of IIM patients.

Objectives: The study included a total of $50 \mathrm{IIM}$ patients who fulfilled the Bohan and Peter 1975 criteria and had skeletal muscle involvement. 27 patients were recruited into the intervention group (IG) and 23 patients into the control group (CG). Both groups received an educational material for home exercise, but only the IG underwent a 6-month intensive training with a subsequent 6-month follow-up period.

Methods: Patients were assessed by a physician and a physiotherapist blinded to intervention at months $0,3,6$, and 12. Patients also filled out patient reported outcomes questionnaires and provided blood for routine laboratory analysis and bio-banking. Data analysis was performed between groups and within the group.

Results: Compared to the observed statistically significant deterioration in the $C G$ over the intervention period, we found a statistically significant improvement in the IG in objectively assessed strength and endurance of muscles as well as in subjectively assessed functional abilities and depression (Table). During the follow-up period, there was a significant deterioration or stagnation of the achieved positive results in the IG. Nevertheless, improved functional ability during the intervention period persisted in the IG in the follow-up period as well. Only numerical improvements in the IG during the intervention compared to the numerical deterioration in CG, that did not reach statistical significance, were observed in some subjectively assessed domains of QoL (SF-36) and fatigue (FIS - in physical dimension).

\begin{tabular}{|c|c|c|c|c|c|}
\hline \multirow[t]{2}{*}{$\begin{array}{l}\text { Parameter } \\
\text { (unit) }\end{array}$} & \multirow{2}{*}{$\begin{array}{l}\text { Intervention } \\
\text { group } \\
\text { Mean } \pm \text { SEM }\end{array}$} & \multirow{2}{*}{$\begin{array}{l}\text { Control } \\
\text { group } \\
\text { Mean } \pm \\
\text { SEM }\end{array}$} & \multicolumn{2}{|c|}{$\begin{array}{c}\text { Intra-group analysis (Friedman } \\
+ \text { +Dunn) }\end{array}$} & \multirow{2}{*}{$\begin{array}{l}\text { Inter-group } \\
\text { analysis } \\
\text { (2WA) }\end{array}$} \\
\hline & & & $\begin{array}{l}\text { Interevention } \\
\text { gr. }\end{array}$ & Control group & \\
\hline MMT8 & $\begin{array}{c}\mathrm{m} 0: 54.7 \pm \\
2.6 \\
\mathrm{~m} 3: 60.7 \pm \\
2.4 \\
\mathrm{~m} 6: 69.1 \pm \\
1.9 \\
\mathrm{~m} 12: 64.0 \pm \\
2.5\end{array}$ & $\begin{array}{c}\mathrm{m} 0: \\
63.6 \pm \\
2.0 \\
\mathrm{~m} 3: \\
57.9 \pm \\
1.8 \\
\mathrm{~m} 6: \\
54.2 \pm \\
1.9 \\
\mathrm{~m} 12: \\
56.5 \pm \\
2.2\end{array}$ & $\begin{array}{c}m 0-3: p<0.01 \\
m 3-6: \\
p<0.0001 \\
m 0-6: \\
p<0.0001 \\
m 6-12: p<0.05\end{array}$ & $\begin{array}{c}\mathrm{m0}-3: \mathrm{p}<0.05 \\
\mathrm{~m} 3-6: \mathrm{NS} \mathrm{m0-6} \text { : } \\
\mathrm{p}<0.0001 \\
\mathrm{~m} 6-12 \mathrm{NS}\end{array}$ & $p<0.0001$ \\
\hline FI-2 (\%) & $\begin{array}{c}\mathrm{m} 0: 30.0 \pm \\
4.4 \\
\mathrm{~m} 3: 46.9 \pm \\
4.7 \\
\mathrm{~m} 6: 70.6 \pm \\
4.9 \\
\mathrm{~m} 12: 58.4 \pm \\
5.8\end{array}$ & $\begin{array}{c}\mathrm{m} 0: \\
38.3 \pm \\
5.3 \\
\mathrm{~m} 3: \\
29.6 \pm \\
4.6 \\
\mathrm{~m} 6: \\
26.1 \pm \\
4.1 \\
\mathrm{~m} 12: \\
25.7 \pm \\
3.6\end{array}$ & $\begin{array}{c}\text { m0-3: } p<0.01 \\
m 3-6: \\
p<0.0001 \\
m 0-6: \\
p<0.0001 \\
m 6-12: p<0.05\end{array}$ & $\begin{array}{c}\text { m0-3: NS m3-6: } \\
\text { NS m0-6: } p<0.01 \\
\text { m6-12: NS }\end{array}$ & $p<0.0001$ \\
\hline HAQ & $\begin{array}{c}\mathrm{m} 0: 0.9 \pm \\
0.2 \\
\mathrm{~m} 3: 0.7 \pm \\
0.1 \\
\mathrm{~m} 6: 0.6 \pm \\
0.1 \\
\mathrm{~m} 12: 0.8 \pm \\
0.2\end{array}$ & $\begin{array}{c}\mathrm{m} 0: 1.3 \\
\pm 0.2 \\
\mathrm{~m} 3: 1.4 \\
\pm 0.2 \\
\mathrm{~m} 6: 1.4 \\
\pm 0.2 \\
\mathrm{~m} 12: \\
1.5 \pm \\
0.2\end{array}$ & $\begin{array}{c}\text { m0-3: NS m3- } \\
\text { 6: NS m0-6: } \\
p<0.01 \\
\text { m6-12: } p<0.05\end{array}$ & $\begin{array}{c}\text { m0-3: NS m3-6: } \\
\text { NS m0-6: NS m6- } \\
12: \mathrm{NS}\end{array}$ & $p=0.0002$ \\
\hline BDI-II & $\begin{array}{c}\mathrm{m} 0: 11.9 \pm \\
2.1 \\
\mathrm{~m} 3: 10.7 \pm \\
1.7 \\
\mathrm{~m} 6: 8.9 \pm \\
1.5 \\
\mathrm{~m} 12: 10.5 \pm \\
2.0\end{array}$ & $\begin{array}{c}\mathrm{m} 0: \\
13.0 \pm \\
1.4 \\
\mathrm{~m} 3: \\
14.3 \pm \\
1.7 \\
\mathrm{~m} 6: \\
15.7 \pm \\
1 . \\
\mathrm{m} 12: \\
16.0 \pm \\
2.0\end{array}$ & $\begin{array}{l}\text { m0-3: NS m3- } \\
\text { 6: NS m0-6: } \\
\text { p<0.05 } \\
\text { m6-12: NS }\end{array}$ & $\begin{array}{c}\text { m0-3: NS m3-6: } \\
\text { NS m0-6: NS m6- } \\
\text { 12: NS }\end{array}$ & $p=0.0025$ \\
\hline
\end{tabular}

Conclusion: Our specialized and intensive ADL workout led to a significant improvement in the observed parameters that was clinically significant in a substantial proportion of patients, and prevention of the expected worsening of muscle weakness and QoL.

Acknowledgement: Supported by AZV-16-33574A, SVV for FTVS UK 2019-260466, MHCR 023728.

Disclosure of Interests: Maja Špiritović: None declared, Sabina Oreska: None declared, Hana Štorkánová: None declared, Barbora Heřmánková: None declared, Petr Česák: None declared, Adéla Rathouská: None declared, Kateřina Kubinova: None declared, Martin Klein: None declared, Lucia Vernerová: None declared, Olga Růžičková: None declared, Heřman Mann Consultant for: Pfizer, Eli Lilly, Sanofi, Speakers bureau: AbbVie, Roche, Pfizer, MSD, Eli Lilly, Sanofi, Karel Pavelka: None declared, Ladislav Šenolt Grant/research support from: AbbVie, Consultant for: AbbVie, Bristol-Myers Squibb, Celgene Corporation, Merck Sharp and Dohme Novartis, Pfizer, Roche, UCB, Amgen, Takeda, Speakers bureau: AbbVie, Amgen, Bristol-Myers Squibb, Celgene Corporation, Eli Lilly, Merck Sharp and Dohme, Novartis, Pfizer, Roche, UCB, Jiří Vencovský Consultant for: Samsung, Speakers bureau: AbbVie, Novartis, Pfizer, Sanofi, Eli Lilly, Biogen, UCB, MSD, Werfen, Roche, Michal Tomčík: None declared

DOI: 10.1136/annrheumdis-2019-eular.1906 